\title{
Characterisation of archaeological high-tin bronze corrosion structures
}

\author{
Ana S. Saraiva ${ }^{1,2}$, Elin Figueiredo ${ }^{1}$, Hugo Águas ${ }^{1}$, Rui J. C. Silva ${ }^{1}$ \\ ${ }^{1}$ Departamento de Ciência dos Materiais, Faculdade de Ciências e Tecnologia, CENIMAT/i3N, \\ Universidade NOVA de Lisboa, Caparica, Portugal \\ ${ }^{2}$ Departamento de Conservação e Restauro, Faculdade de Ciências e Tecnologia, Universidade \\ NOVA de Lisboa, Caparica, Portugal
}

\begin{abstract}
Since ancient times the use of high-tin bronze alloys (>17 wt.\%) has been mainly limited to the production of specific objects such as mirrors and bells. High-tin bronzes can show distinctive colour reflection, as well as mechanical properties and corrosion resistance that clearly distinguish it from the classical bronze composition (with 8-12 wt.\% Sn). In the present study samples of archaeological high-tin bronze bells were studied by optical microscopy, SEM-EDS and Raman imaging with the aim of characterising their microstructural long-term corrosion patterns. Results show the presence of high quantities of $\delta$ phase, when compared to the classical bronze composition, which makes some corrosion structures more visible in these alloys. The corrosion morphologies show selective corrosion of different metal phases along depth of corrosion, which were attributed to different oxygen potentials. This study proposes a classification of four types of corrosion structures occurring in two phase bronzes as a consequence of aeration conditions during burial time and aeration within the corrosion structure.
\end{abstract}

Keywords: Archaeological artefacts; Bells; High-tin bronze; Long-term corrosion

\section{Introduction}

Throughout history, the use of high-tin bronze alloys (>17 wt.\%) was mainly reserved to the fabrication of specific objects of noted importance, mostly mirrors and bells. In Ancient China and Rome an alloy with 24-26 wt.\% Sn and c. 8 wt.\% Pb was used for mirrors fabrication [1]. In China, an alloy with 4 to 5 parts of $\mathrm{Cu}$ and 1 part of Sn, corresponding to a copper with 20-25 wt.\% Sn, has been used since the $5^{\text {th }}$ century BC for bells [2-4]. According to different treatises, books of recipes and encyclopedias [3,5-8], the composition of bell bronze has been kept almost constant, with the exception of some medieval bells in central Europe were the composition dropped to 12 wt.\% Sn $[2,4]$. Nowadays, bell industry has maintained a traditional manufacturing path, still using high-tin bronze for bell production. This choice is strongly linked with its mechanical resistance and, above all, its sound resonance [3,9].

In Europe, the casting of bells began in Italy at the end of the $6^{\text {th }}$ century AD by the Benedictines [2] and its use becomes more common during the Middle Ages, especially associated with the development of the Catholic Church, since bells are an essential element in Christian practice [10, 11]. Since their introduction in Europe, bells have been used for a variety of activities and contexts: demarcation of time; alarm in risk situations; healing through their apotropaic capacities and; when combined, tuned and associated with a keyboard to form a carillon, for music $[2,10,12,13]$. Thus, bells have been a central object in the life of many peoples, being a symbol for the administrative power and opulence of the population, as well as a means for the affirmation of cultural identities [12-14].

Despite the wide recognition of bells and bell bronze, studies on specificities of high-tin bronze corrosion are rare. This can be due to the recurrent recasting of these objects and to the difficulty in reproducing long-term corrosion patterns in laboratorial conditions. 
In the present work, high-tin bronze archaeological samples (both of bells and bell bronze from foundry pits) were analysed with the aim of characterising different corrosion structures observed in depth profiles. After the analysis, the various corrosion patterns were associated to selective corrosion of different metal phases at different depths, and a classification in four main types of corrosion structures occurring in high-tin bronzes is proposed as a variation of aeration conditions.

\subsection{High-tin bronzes microstructure}

The classical composition of tin bronze objects compromises a Sn content usually between 8-12 wt.\% Sn [15], resulting very frequently in a monophasic structure, composed of $\alpha$ phase. According to the $\mathrm{Cu}-\mathrm{Sn}$ metastable phase diagram, high-tin bronzes with $20-25$ wt.\% Sn, are composed by biphasic structures composed by the $\alpha \mathrm{Cu}$-rich phase and the intermetallic $\delta$-phase with $\approx 32$ wt. $\% \mathrm{Sn}$. In cast alloys, these microstructures consist essentially in a primary a dendritic matrix plus an interdendritic eutectoid $(\alpha+\delta)[4,8,9]$. The relative proportions of each phase varies in accordance with the Sn content and the cooling rate [4]. A low cooling rate leads to larger dendrite structures and will tend to low amounts of internal porosities, while a higher cooling rate will increase the eutectoid amount [4]. Nevertheless, if the alloy reaches more than $25 \mathrm{wt}$ \% Sn, a very distinctive microstructure can appear: alloys with $27 \mathrm{wt} . \%$ Sn will show absence of primary a phase and presence of a very fine microstructure composed only by eutectoid; bronzes with 27 to $33 \mathrm{wt} . \%$ Sn will have the a phase grains replaced by proeutectoid $\delta$ phase grains, with the eutectoid $(\alpha+\delta)$ in between (Fig. 1) [16, 17].

For bronze and high-tin bronze manufacturing, lead has been traditionally added to improve castability and to adjust the mechanical properties of the alloy [19-22]. Given the low solubility of lead in copper, this element is segregated to the liquid during solidification and will solidify at lower temperatures as small $\mathrm{Pb}$-rich globules $[19,21]$, which can be easily detected in the microstructures. 


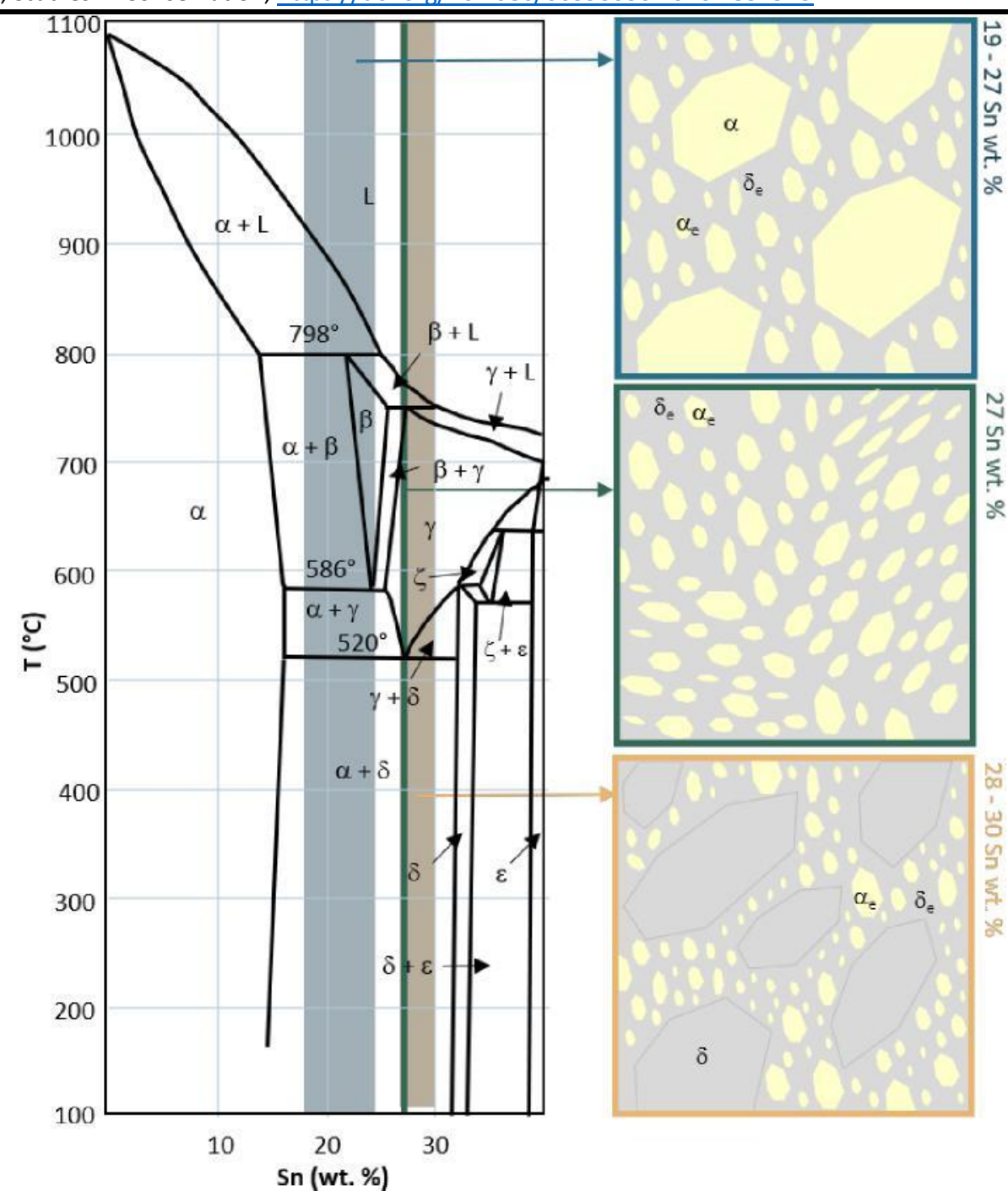

Fig. 1. Cu-Sn metastable phase diagram for annealing conditions adapted from Atlas Metallographique Des Alliages Cuivreux [18] and schematic microstructures of high-tin bronzes alloys with different Sn contents (19-27 wt.\% Sn; 27 wt.\% Sn; 28-30 wt.\% Sn).

\subsection{Background on corrosion of tin bronze}

One of the principal mechanisms of bronze corrosion is decuprification, which can be summarized as the preferential leaching of oxidized copper species, and described in three main steps: (1) alloy dissolution and formation of a passive (Type I) layer or non-passive (Type II) layer at the surface; (2) corrosion propagation controlled by the possibility of ion transportation through the preformed corrosion layer; (3) corrosion evolution due to environmental alterations during burial time [23]. This mechanism has been observed in several case studies [21, 24-27]. The occurrence of Type I or Type II morphologies has been described as related to the level of aggressiveness of the environment. An important difference, especially when dealing with cultural artefacts, is the preservation of the limit of the original surface that, in Type I remains close to the surface, making it possible to maintain the legibility of the object, whereas in Type II the original limit is completely disrupted [23].

According to the few studies on archaeological high-tin bronzes [28, 29], the major difference to the corrosion behaviour of common tin bronzes is the corrosion rate and the ability to form passivating layers. The most common crystalline tin oxide found in tin corroded artefacts is cassiterite $\left(\mathrm{SnO}_{2}\right)[30,31]$. Cassiterite is very stable in almost every natural environments and has the ability to form a strong passive layer [32, 33]. According to Muller et al. [34], a higher tin content helps to create a thicker passive layer, rich in Sn compounds, quicker. The passive 
Saraiva, A.S., Figueiredo, E., Águas, H., Silva, R.J.C. (2020) Characterisation of Archaeological High-tin Bronze Corrosion Structures, Studies in Conservation, https://doi.org/10.1080/00393630.2020.1857523.

behaviour of the tin oxide layer formed in high-tin bronzes is therefore more efficient $[34,35]$. However, a higher tin bronze cannot be considered nobler [34, 36]. The Gibbs free energy of formation of cuprite $(-146 \mathrm{~kJ} / \mathrm{mol}$ at $298 \mathrm{~K})$ and stannic oxide $\left(\mathrm{SnO}_{2}\right)(-519 \mathrm{~kJ} / \mathrm{mol}$ at $298 \mathrm{~K})$ favours the formation of the latter. Nevertheless, since $\mathrm{SnO}_{2}$ is practically insoluble in water, a high-tin bronze will tend to preserve a thicker tin-rich layer [34, 36, 37]. Note that, in bronzes cassiterite is mostly found in hydrated conditions and/or with some degree of ionic substitution in the mineral lattice. Several studies conducted on archaeological high-tin leaded bronze mirrors [1, $24,29,38$ ] have confirmed the high stability of these alloys with the presence of unaltered metal.

\section{Materials and methods}

\subsection{Samples}

Four samples of archaeological high-tin bronze fragments were selected to study the long-term corrosion. The artefacts are from different origins and contexts, all within the Portuguese territory, and from a time span from the $13^{\text {th }}$ to the $19^{\text {th }}$ centuries (Table 1 ).

Table 1. Description of analysed samples of high-tin bronze.

\begin{tabular}{|l|l|l|}
\hline Sample & Attribution & Description \\
\hline $\begin{array}{l}\text { Coruche (Santarém } \\
\text { Central Portugal) }\end{array}$ & 1287 & $\begin{array}{l}\text { Broken medieval bell belonging to the church of S. Pedro, de Coruche [3, } \\
22] .\end{array}$ \\
\hline $\begin{array}{l}\text { Tarouca (Viseu, North } \\
\text { Portugal) }\end{array}$ & $13^{\text {th }}-14$ th centuries & $\begin{array}{l}\text { Bell fragment found on a pre-existing bell foundry pit at S. João de } \\
\text { Tarouca Monastery [3]. }\end{array}$ \\
\hline $\begin{array}{l}\text { L'Ócean (Algarve, South } \\
\text { Portugal) }\end{array}$ & $18^{\text {th }}$ century & $\begin{array}{l}\text { Fragment of a high-tin alloy, probably from a bell, recovered from } \\
\text { L'Ócean, a French flagship } \\
\text { that shipwrecked during the Seven Years' War in the Battle of Lagos on } \\
19 \text { August 1759, after being set on fire [39, 40]. }\end{array}$ \\
\hline $\begin{array}{l}\text { Famalicão (Braga, North } \\
\text { Portugal) }\end{array}$ & $18^{\text {th }}-19^{\text {th }}$ centuries & $\begin{array}{l}\text { Fragment from the remains of a bell foundry belonging to the Church S. } \\
\text { Silvestre de Requião in Vila Nova de Famalicão. }\end{array}$ \\
\hline
\end{tabular}

\subsection{Sample preparation and analytical techniques}

Cross-sections of the fragments were cut using a fine jeweller's saw, followed by a conventional metallographic preparation. The samples were mounted using acrylic resin, then polished with $\mathrm{SiC}$ abrasive papers of successively smaller granulometries and finished with a $1 / 4 \square \mathrm{m}$ diamond suspension. The samples were analysed by optical microscopy (OM) using bright field and polarized light, in unetched conditions.

OM observations were made with a Leica DMI5000M microscope coupled with a Leica DFC295 digital camera. Both instruments are connected to a computer equipped with Leica Application Suite (LAS V4.9) software, with multifocus functionality [41].

Scanning electron microscopy (SEM) analysis were made using a Zeiss DSM 962 with a secondary electron detector (SE), backscattered electrons detector (BSE) and an energy dispersive spectrometer (EDS) from Oxford Instruments INCAx-sight. The EDS system has an SDD detector, with PentaFET precision and a resolution of $125 \mathrm{eV}$ to a $\mathrm{Mn} \mathrm{K \alpha}$ at 5,9 $\mathrm{keV}$, with the ability to detect atomic numbers greater than five. The observations were carried out using a working distance of $25 \mathrm{~mm}$ and acceleration voltage of $20 \mathrm{kV}$. BSE imaging was chosen due to the high atomic number contrast. For the microanalysis the acquisition time was set at $120 \mathrm{~s}$ live time for X-ray spectra and for a level 4 of processing time. Elemental semi-quantifications were made using ZAF correction factors.

For analysis and images with higher resolutions a SEM-FIB - Zeiss Auriga CrossBeam system was used (field emission SEM, $<1 \mathrm{~nm}$ beam spot size at maximum resolution). The equipment has an EDS detector by Oxford instruments, model X-Max, with $150 \mathrm{~mm}^{2}$ of active area. The presented mappings were conducted with 150 pts with $10 \mathrm{~s}$ acquisition time per point. 
Saraiva, A.S., Figueiredo, E., Águas, H., Silva, R.J.C. (2020) Characterisation of Archaeological High-tin Bronze Corrosion Structures, Studies in Conservation, https://doi.org/10.1080/00393630.2020.1857523.

Raman analysis were carried out with a Renishaw Qontor Raman Microscope with $532 \mathrm{~nm}$ and $633 \mathrm{~nm}$ lasers, spectral resolution of $0.3 \mathrm{~cm}^{-1}$ (FWHM), and a mapping capability with $100 \mathrm{~nm}$ of lateral resolution and real time dynamic auto focus. The Raman unpolarized scattering spectra were recorded with a $\mathrm{Nd}^{-} \mathrm{YAG}$ DPSS laser source of $532 \mathrm{~nm}$ wavelength, with 2 accumulations of $3 \mathrm{~s}$ acquisition time each at $50 \%$ of maximum power (max. $50 \mathrm{~mW}$ ) and $1800 \mathrm{~L} . \mathrm{mm}^{-1}$ grating in a microscopic configuration (Leica OM microscope), using a $100 \times$ objective lens.

\section{Results and Discussion}

\subsection{Microstructure}

All the analysed samples are high-tin bronzes, with a tin content ranging from 19 to $27 \mathrm{wt} \%$, and low amounts of lead ( $<3$ wt.\%) (Table 2). It can be considered that the composition of the alloys is in accordance with the theoretical values for bell bronzes (20-25 wt.\% Sn), with small deviations.

Table 2. Alloy composition of each sample (SEM-EDS analysis).

\begin{tabular}{lccc} 
Sample & $\mathbf{C u}(\mathbf{w t . \%})$ & Sn $\mathbf{( w t . \% )}$ & $\mathbf{P b}(\mathbf{w t . \% )}$ \\
\hline Coruche & 75.6 & 21.3 & 3.0 \\
Tarouca & 72.7 & 27.3 & n.d. \\
L'Ócean & 79.3 & 19.4 & 1.3 \\
Famalicão & 78.3 & 21.8 & $<1.0$ \\
\hline
\end{tabular}

n.d. - not detected

OM metallographic observations of all the cross-sections show that the metal fragments have microstructural characteristics of as-cast high-tin bell bronzes (Fig. 2), with the exception of Tarouca's sample (Fig. 2 - d), where almost the entire microstructure is composed of $(\alpha+\delta)$ eutectoid. This is concordant with the obtained composition by SEM-EDS and the microsctructure prediction shown in Fig. 1, indicating an alloy composition close to the eutectoid reaction ( $27 \mathrm{wt} . \% \mathrm{Sn}$ ). The distribution of the porosities observed in this sample seems to follow a pre-existing dendritic structure, likely the primary solid phase, $\gamma$ phase, suggested also by the different orientations presented by the eutectoid mixture (Fig. 2d).

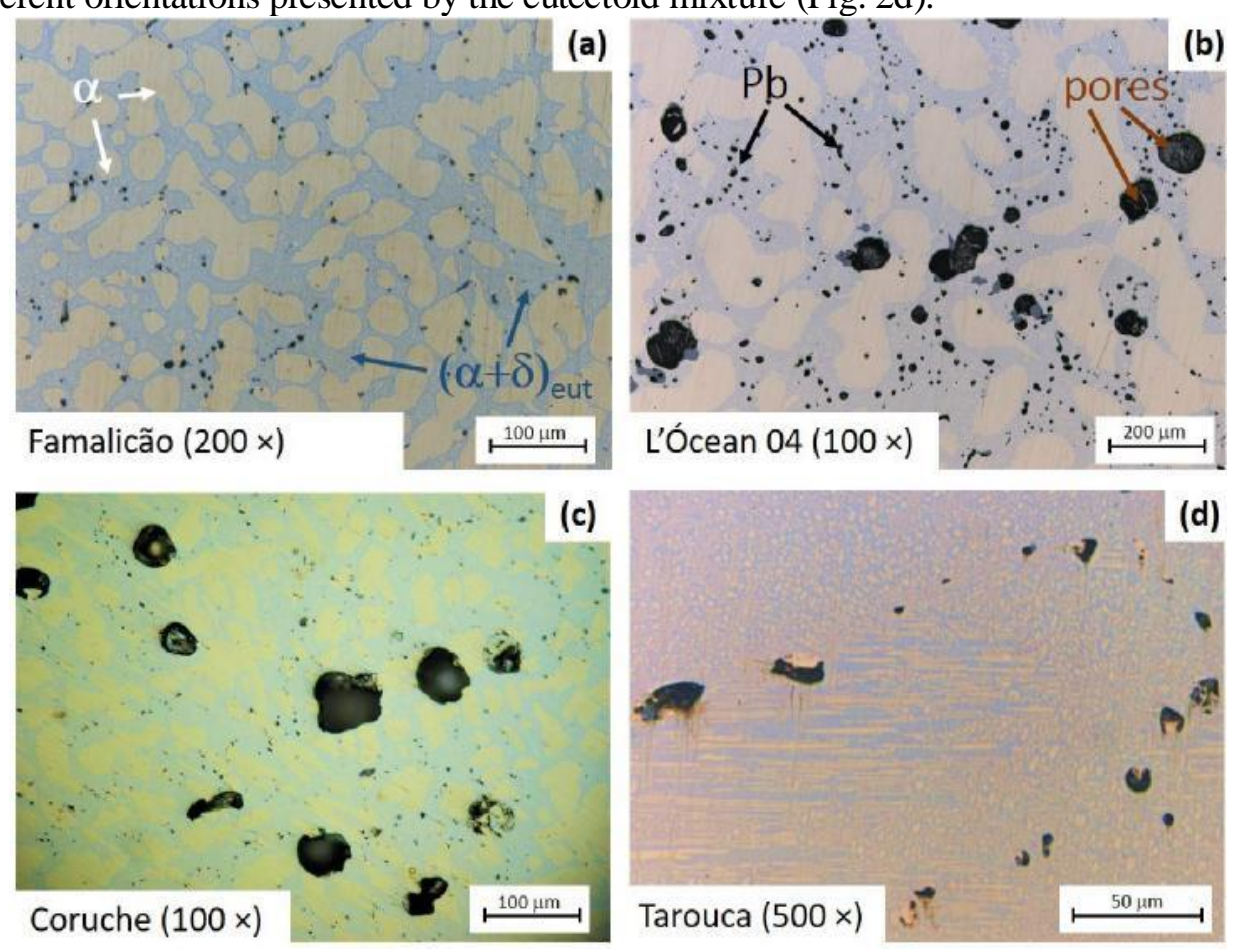

Fig. 2. OM bright field images of the samples uncorroded microstructures with visible $\alpha$ phase grains (yellow), $(\alpha+\delta)$ eutectoid (blue-grey colour) and some porosities (black colour). (a) Famalicão, $200 \times$; (b) L’Ócean, $100 \times$; (c) Coruche, $100 \times$ and (d) Tarouca, $500 \times$. 


\subsection{Corrosion Structure}

A stratified corrosion structure with various sublayers of altered products was observed in all the samples at OM. These structures can be organized into two main layers distinguished by precipitation mechanisms: (1) one external layer formed by corrosion products resulting from the leaching of metal ions to the surface of the object, and (2) one internal layer resulting from in situ precipitation of the corrosion products, without a significant morphological alteration of the original microstructure (pseudomorphic alterations).

Focusing on the external layer (1), this can be divided into two sublayers: (1a) a more superficial one, with greenish colour, mainly composed by $\mathrm{Cu}[\mathrm{II}]$ products, and (1b) an inner layer with reddish/orange colours, due to the presence of high amounts of cuprite $\left(\mathrm{Cu}_{2} \mathrm{O}\right)$ and other copper-tin intermediate compounds originating the orange colours observed under polarized light [42]. The internal corrosion layer (2) can also be divided in two different

sublayers: (2a) nearer to the surface, presenting preferential corrosion of the $\alpha$ phase $(\mathrm{Cu}$ rich), and its pseudomorphic replacement, mostly with cuprite, being the $\delta$ phase present without corrosion; and a deeper internal layer (2b) with preferential corrosion of the $\delta$ phase (richer in $\mathrm{Sn}$ ), and redeposition of metallic copper, mainly in pre-existing voids, cracks and grain boundaries, without $\alpha$ phase corrosion (Fig. 3). Not all sub-layers were present in all the samples. The particularities of each corrosion feature will be discussed in more detail hereafter. To facilitate, the nomenclature given to each sublayer is schematized in Fig. 3, and will be adopted from now on.
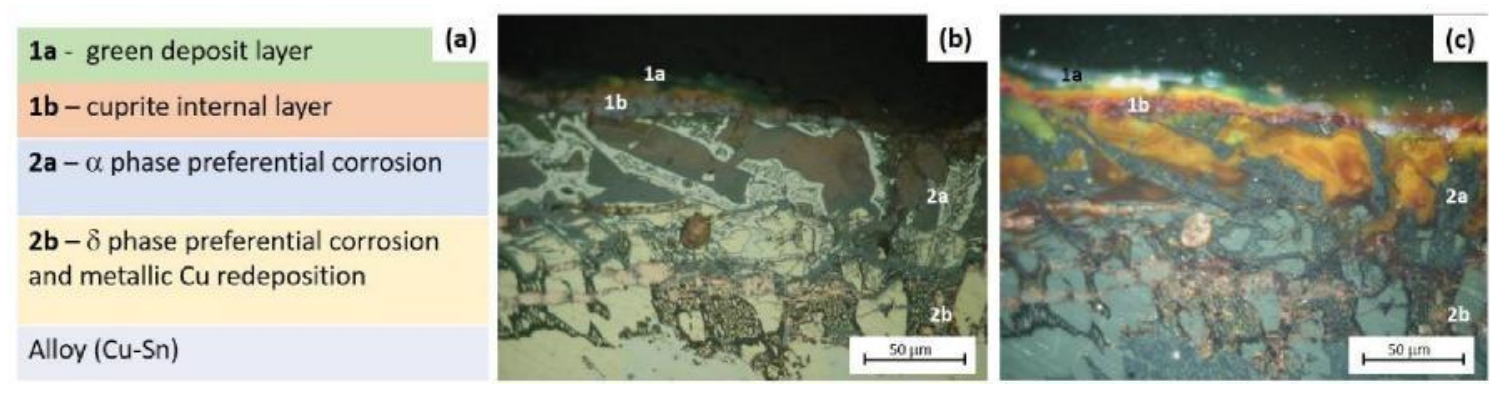

Fig. 3. (a) Schematic representation of the different layers observed. (b) OM bright field image of Coruche's cross-section $(500 \times)$ and $(c)$ respective image under polarised light $(500 \times)$.

In L'Ócean sample (Fig. 4), sublayer $2 \mathrm{~b}$ is not present, and sublayer 2a presents large corrosion voids (up to $70 \mu \mathrm{m}$ ) filled with a thin film of in-situ formations of cuprite and external contaminants. On the exterior surface, a layer (1) of greenish $\mathrm{Cu}[\mathrm{II}]$ products deposits can be seen with sand particles incorporated. The presence of large voids associated with a thin inner corrosion layer with external contaminants (2a) suggest a high rate of dissolution of the bronze material, especially among the $\alpha$ phase. Between layers 1 and 2, a dark thin layer (Fig. 4b) is observed. This is a consequence of a higher concentration of Sn corrosion products (confirmed by SEM-EDS analysis), due to its higher chemical stability and insolubility, comparatively to the $\mathrm{Cu}$ salts. The fact that this artefact was in an underwater environment for more than two centuries may be the reason for the high dissolution observed.

OM observations of the corrosion sublayer 1b of Famalicão's sample under polarized light (Fig. 5) show a ghost mineralized structure of the original $\alpha-\mathrm{Cu}$ phase, filled with orange coloured products (under polarized light) and the maintenance of the $\delta$ phase uncorroded, suggesting the occurrence of a pseudomorphic transformation [43]. On the interface between sublayer $1 \mathrm{~b}$ and sublayer 1a, the transformation of orange coloured into greenish coloured products (Fig. 5) indicates the gradual oxidation of cuprite to basic copper [II] compounds. 


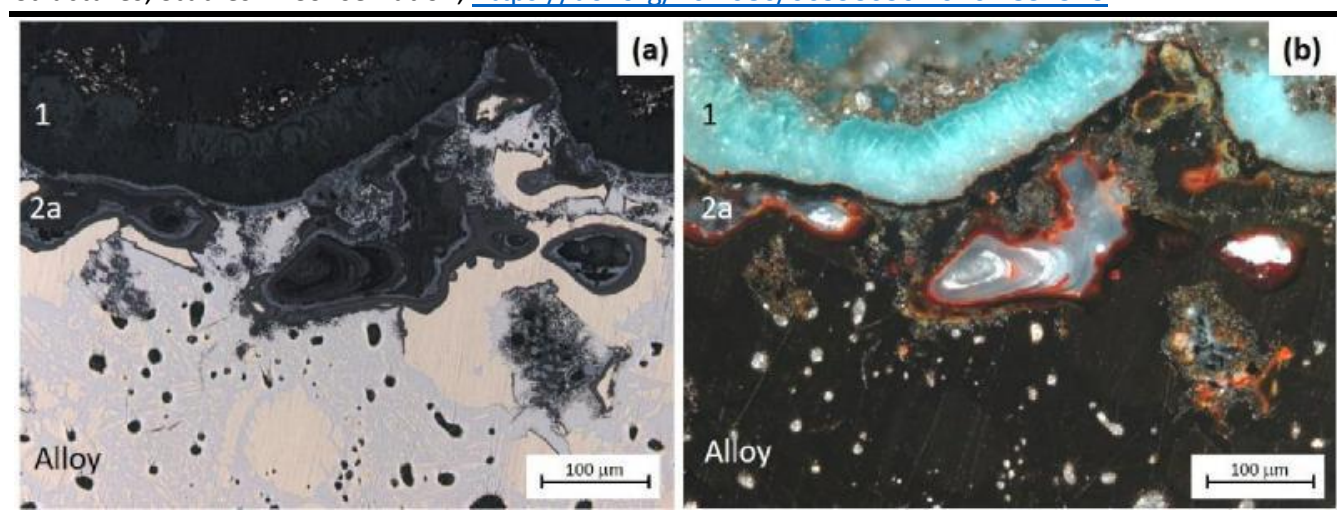

Fig. 4. Detail of the cross-section from L'Ócean fragment. (a) OM bright field image $(200 \times)$; and (b) respective polarized light image $(200 \times)$.
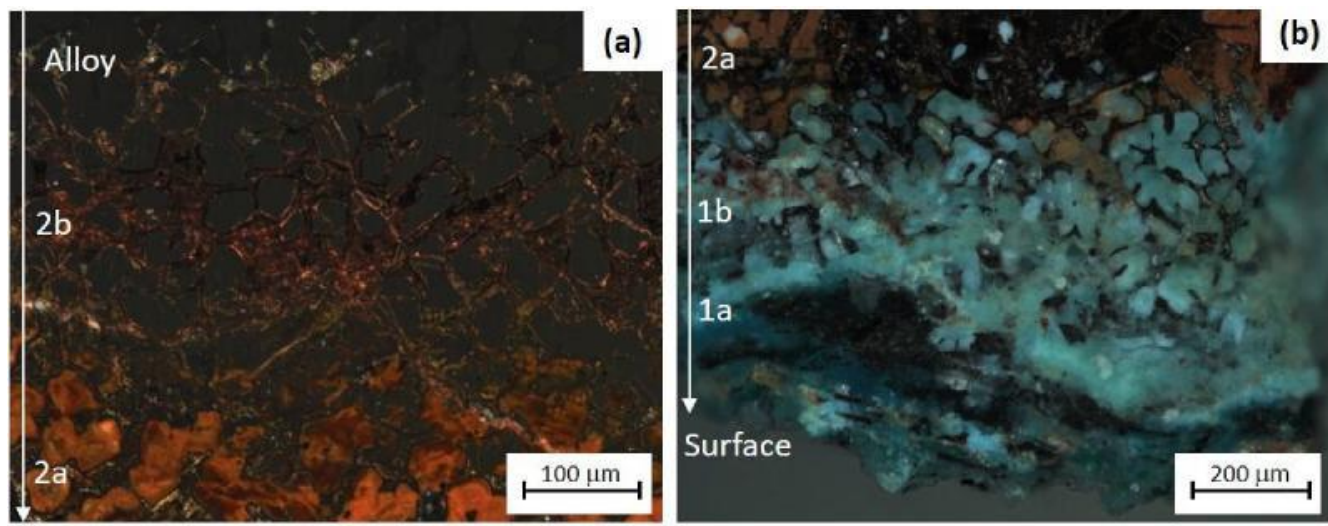

Fig. 5. OM polarized light detail images of Famalicão cross-section. (a) Pseudomorphic cuprite formed in sublayer 2a is visible on the bottom part of the image $(200 \times)$. (b) A ghost mineralized structure of the original $\alpha$ phase filled with $\mathrm{Cu}$ [II] species (green) is seen in image $(100 \times)$. Under polarized light observations, the metallic phases appear darker.

In Tarouca's sample (Fig. 6), a macroscopic void (>3 mm) is present near the centre of the crosssection. In the surface near this void, the cuprite layer (1b) is well developed and the green layer (1a) appears dispersed indicating low access to oxygen (that otherwise would oxidise cuprite to $\mathrm{Cu}[\mathrm{II}]$ products). Along the surface of the sample, sublayer 1a is also not observed and the welldeveloped cuprite layer seems to follow the limit of the original surface of the fragment. The non-existence of the exterior sublayer 1a may $\mathbf{A}$ be a consequence of cleaning operations performed after the finding of the object causing its detachment and loss. 


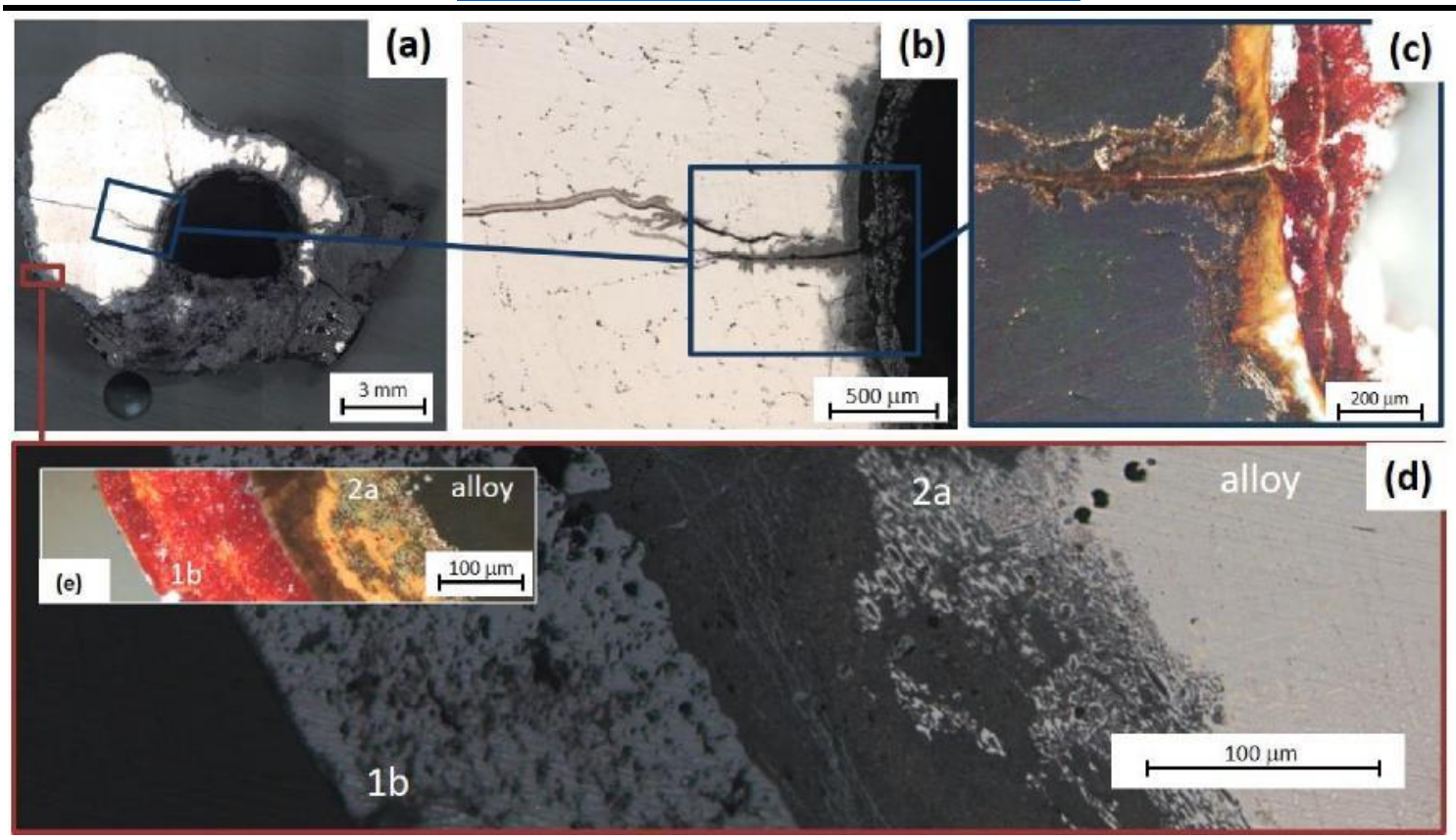

Fig. 6. OM detailed images of Tarouca cross-section. (a) Bright field image of the cross-section. (b) Bright field image showing a crack initiated at the macroscopic void (internal surface) of the object $(50 \times)$ and (c) respective polarized image $(100 \times)$. (d) Bright field image of the external corrosion layer (ex-situ deposited corrosion products, $1 b)$ and the internal corrosion layer (2a) with $\alpha$ and 6 phase uncorroded $(200 \times)$. The corrosion front (on the right side) shows intergranular corrosion of $\alpha$-cu grains with 6 phase uncorroded. (e) Corresponding polarized light image.

Regarding the original surface limit, it is possible to observe that both L'Ócean and Famalicão samples don't preserve the limit of the original surface. This may be a direct result of the corrosion process, as the exposure to very aggressive environments or due to detachment of the exterior layers during burial or post-excavation procedures. In Tarouca's sample, the original limit of the surface is still conserved in the internal/external corrosion layers interface, the same for the Coruche bell, indicating a Type I corrosion structure [23] with modifications concerning biphasic ( $\alpha$ and $\delta$ ) structures.

\subsection{Corrosion mechanism}

\subsubsection{Preferential corrosion of $\alpha$ phase}

Aiming to clarify the mechanism of corrosion occurring on high tin bronze materials, spot SEMEDS microanalysis were conducted in $\alpha$ grains in the bulk (non-oxidized) and in sublayer 2a (in oxidized conditions) of some samples. In Famalicão, these analyses revealed a high decrease of the $\mathrm{Cu} / \mathrm{Sn}$ ratio due to the $\alpha$ phase corrosion, from 10.7 at/at (corroded) to 1.0 at/at (metal). This process of copper loss by preferential leaching is result of the "decuprification" mechanism [23]. The dissolution factor $\left(f_{C u}\right)$, defined by L. Robbiola et al. [23] as $0.94 \pm 0.04$, is 0.90 for the analysed $\alpha$ phase corrosion of the sample, and thus within expected values. The extension of the decuprification is visible in the X-ray elemental maps of Famalicão cross-section (Fig. 7), showing a tin enriched surface, and the ex-situ deposition of copper corrosion products both in cracks and in the external corrosion layer (right top corner in the image). Most of the metallic copper redeposited in cracks appears oxidized, mainly to cuprite. 


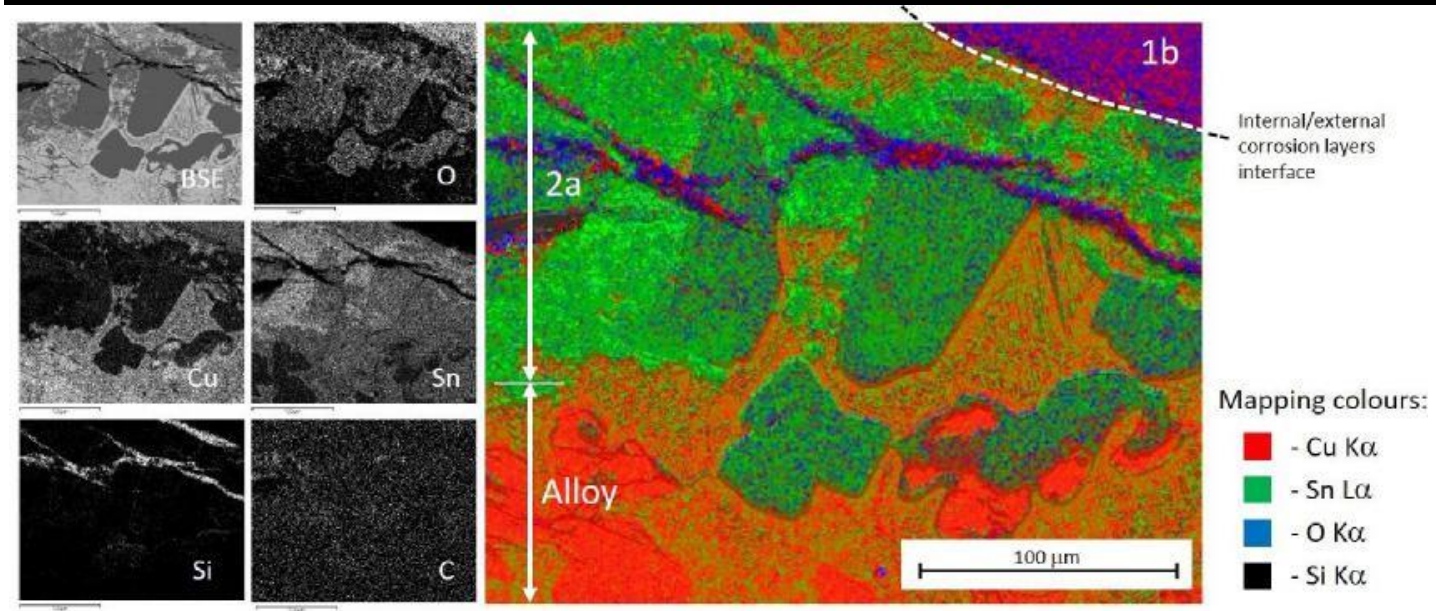

Fig. 7. SEM-EDS X-ray mapping of an area next to the surface of Famalicão cross-section. EDS elemental maps that confirm that sublayer $2 \mathrm{a}$ is subject to a high degree of decuprification and the external layer $(1 \mathrm{~b})$ is much richer in copper corrosion products by an ex-situ cuprite deposition.

Similar analysis conducted on L'Ócean sample showed the occurrence of an intense decuprification phenomenon, with high copper leaching and contamination of sea species. The $\mathrm{Cu} / \mathrm{Sn}$ atomic contents in three sublayers are 43.3/1.4 (1a), 24.0/9.6 (1b) and 8.0/14.5 (2a) (Fig. 8). Comparing the values from the internal layer (2a) with the values of the external sublayers (1a and $1 \mathrm{~b})$ a significant increase in copper content from the interior to the exterior is visible. This can be explained by a substantial decuprification in the internal layer (2a) accompanied by the precipitation of $\mathrm{Cu}[\mathrm{II}]$ compounds in the external layers (1), and the preservation of the $\mathrm{Sn}$ compounds in the inner layer (2a). Detailed observations of the object's surface, show regions where layer 1 was completely detached, likely due to mechanical destruction of the external layers in this object. The relative low chlorine concentrations observed in the corrosion structure of L'Ócean bell whose provenance was a shipwreck can be explained by a fast leaching of chlorine-rich corrosion products.
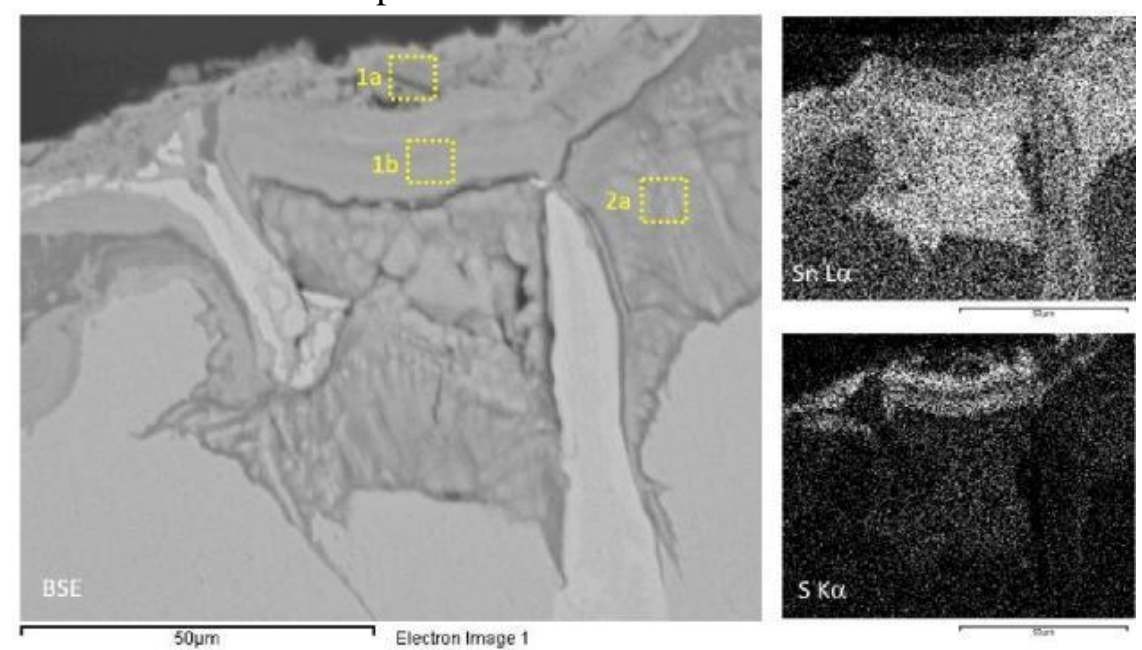

Fig. 8. BSE-SEM image of the corrosion layers in L'Ócean cross-section and EDS elemental maps for Sn-L $\alpha$ and S-K $\alpha$.

The detailed observation of the preferential corrosion of the a phase in sublayers $2 \mathrm{a}$ of Coruche sample (Fig. 9) shows that corrosion progresses along the grain boundaries (intergranular corrosion) and then progresses gradually to the interior of the grains with some developments along certain preferential $\alpha$-Cu crystallographic directions (transgranular corrosion). 

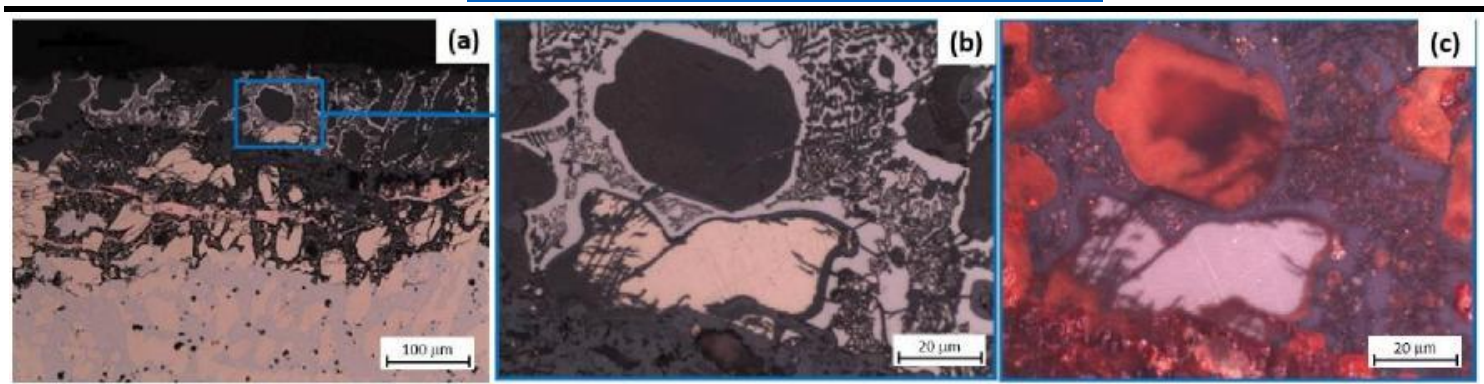

Fig. 9. OM detail image of Coruche cross-section showing the preferential corrosion of the a phase and the nonoxidation of ö phase in sublayer 2a. (a) Bright field $(200 \times)$; (b) bright field $(1000 \times)$ and (c) corresponding polarized light image $(1000 \times)$.

In the regions of $\alpha$ phase corrosion, $\delta$ phase remains uncorroded. According to the Pourbaix diagram for $\mathrm{Sn} / \mathrm{H}_{2} \mathrm{O}$, cassiterite is the most stable oxide in a wide range of environments [25] and its formation is thermodynamically favourable in almost all natural conditions, the only exceptions being conditions of extreme $\mathrm{pH}$. Thus, the preferential oxidation of a phase may be justified by the formation of $\mathrm{Sn}[\mathrm{IV}]$ oxide, favouring the passivation of the $\delta$ phase $[30,44]$ and favoring corrosion and leaching of $\mathrm{Cu}$ species from the $\alpha$ phase.

A SEM-EDS spot analysis performed on Famalicão fragment of the copper oxide deposited in a pore located in sublayer $2 \mathrm{a}$ (less affected by soil contaminants) provided an $\mathrm{O} / \mathrm{Cu}$ atomic ratio close to 0.47 . This ratio points out to the formation of cuprite $\left(\mathrm{Cu}_{2} \mathrm{O}\right)$, confirming the preferential oxidation of copper to cuprite in these internal regions (2a), as predicted by the Pourbaix diagram for $\mathrm{Cu} / \mathrm{H}_{2} \mathrm{O}$ [45].

An elemental line scan conducted in an area of $\alpha$ phase preferential corrosion of Famalicão's sample (Fig. 10), shows a clear fluctuation of $\mathrm{Cu} / \mathrm{Sn}$ ratios during pseudomorphic oxidation of the $\alpha$ grains. These elemental fluctuations can be the result of periodic variations of the leaching of $\mathrm{Cu}$ and $\mathrm{Sn}$ oxide species during the corrosion progression into the grain due to alteration conditions in the soil, such as $\mathrm{pH}$ and contaminant concentrations. Scott $[43,46]$ suggests that this banded structures can be explained by a Liesegang phenomenon, associated to a cycle of supersaturationnucleation-depletion. It has also been suggested that this phenomena could be more pronounced in the presence of specific chemical species, like hydrated tin oxides $\left(\mathrm{SnO}_{2} \cdot \mathrm{xH}_{2} \mathrm{O}\right)$ which are known to form amorphous gel-like compounds [34].
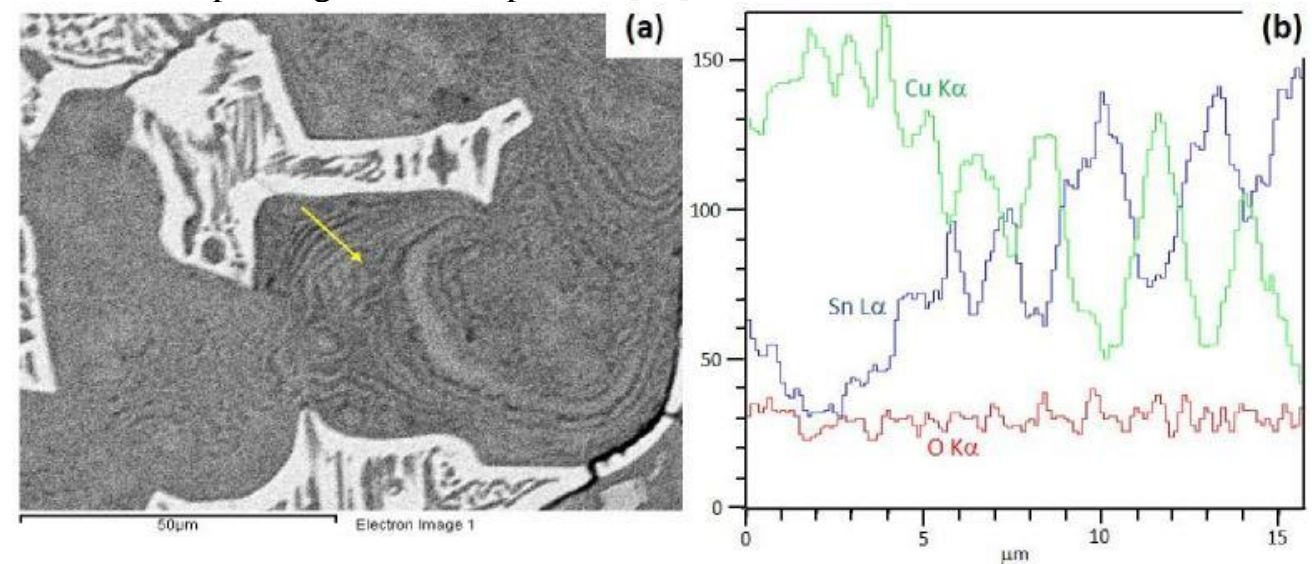

Fig. 10. (a) BSE-SEM detailed image of periodic corrosion of $\alpha$ phase in Famalicão's sample. (b) EDS line scan of periodic corrosion in primary $\alpha$ phase grains. The represented curves are the measure intensities from O-K $\alpha, \mathrm{Sn}-\mathrm{L} \alpha$ and $\mathrm{Cu}-\mathrm{K} \alpha$ characteristic emissions along a selected line (marked as a yellow line in the left BSE image). 
Saraiva, A.S., Figueiredo, E., Águas, H., Silva, R.J.C. (2020) Characterisation of Archaeological High-tin Bronze Corrosion Structures, Studies in Conservation, https://doi.org/10.1080/00393630.2020.1857523.

The corrosion products formed on the exterior corrosion layer (1a) show a strong influence of the burial environment composition, causing the formation of different copper [II] species, frequently mixed with elements originating from the soil.

\subsubsection{Preferential corrosion of $\delta$ phase}

In the most internal regions of the samples, sublayers $2 b$, the principal mechanism occurring is the preferential corrosion of the Sn-rich $\delta$ phase with the subsequent redeposition of metallic copper in the pre-existing cracks, pores and along the a grains boundaries (Fig. 11). This phenomenon was found in Tarouca, Famalicão and Coruche samples.
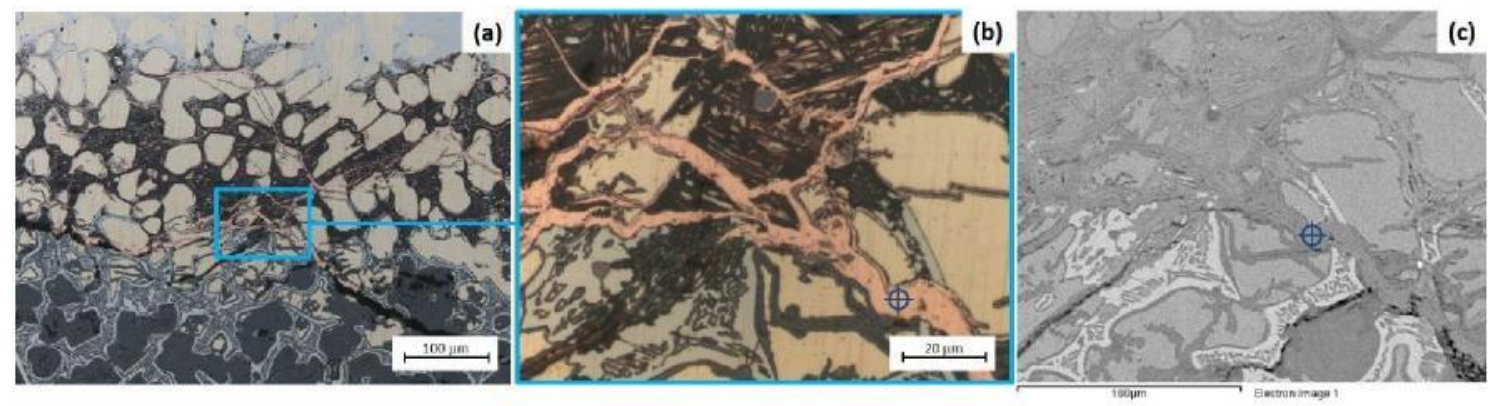

Fig. 11. (a) Detailed OM bright field image of sublayer 2b of Famalicão cross-section, showing corroded $\delta$-phase (black coloured) and redeposited metallic copper (pink) in the available spaces $(200 \times)$. (b) Higher magnification OM bright field image of the area marked in the previous image $(1000 \times)$ and (c) BSE-SEM image obtained in the same area showing redeposited copper in the interface between sublayers $2 \mathrm{a}$ and $2 \mathrm{~b}$. An analyzed spot $(99.1 \mathrm{at} . \% \mathrm{Cu})$ is depicted with a target in (b) and (c).

Spot SEM-EDS analysis of the pink-colored copper deposited in cracks and small pores indicates a copper content of 99.8 wt.\% (99.1 at.\%) which confirms almost pure redeposited copper. In Tarouca's sample, $\delta$ corrosion and redeposited copper is observed at internal cracks originating from the surface. Detailed images show a continuous copper redeposited band enclosed by a thin layer with corroded ö phase (Fig. 12).
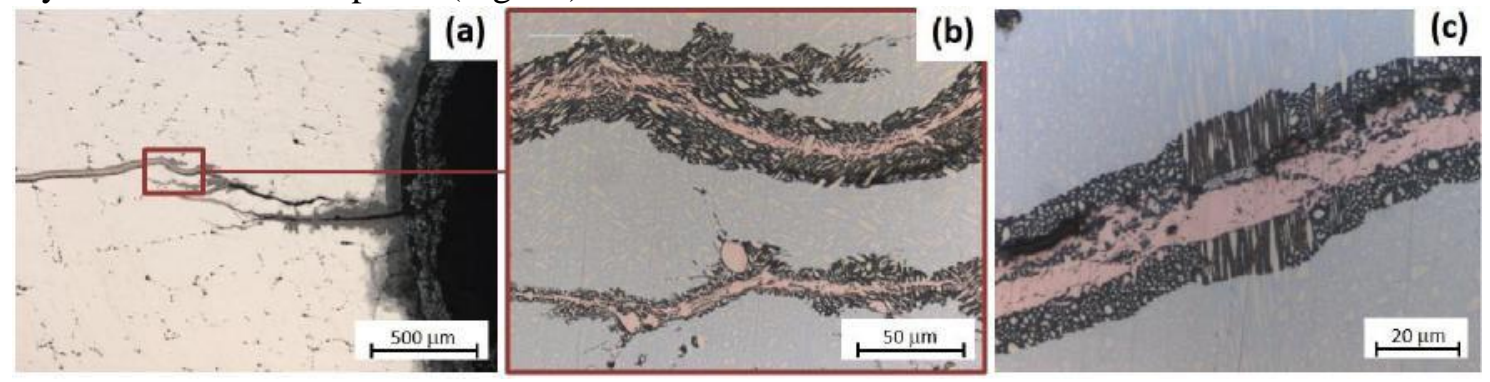

Fig. 12 - Detailed OM bright field observations of the corrosion region adjacent to the cracks initiated at the internal surface of the cross-section of the Tarouca fragment: (a) general view of the crack $(50 \times)$, (b) higher magnification image corresponding to the white rectangle region in previous image $(500 \times)$; (c) higher magnification of another internal crack showing preferential corrosion of the ö phase and its filling with redeposited metallic copper $(1000 \times)$.

In fact, the mechanism of redeposited $\mathrm{Cu}$ observed in bronzes show similarities to the dezincification process in brasses [24, 47, 48] where the preferential leaching of zinc occurs, leaving a porous and brittle copper rich area near the surface [47, 48]. In bronzes, this phenomenon is explained by the preferential oxidation of tin in $\delta$ phase at low oxygen potential conditions $[44,48]$. The mechanism proposed for this occurrence is based in the oxidation of both $\mathrm{Sn}$ and $\mathrm{Cu}$ in the ö phase but, since the oxidised $\mathrm{Cu}$ species are unstable at low electrochemical potentials, a subsequent reduction and precipitation of copper in the nearby available spaces will happen $[24,48,49]$. The metallic $\mathrm{Cu}$ redeposition phenomenon is associated with low aerated 
environments [32, 48-50]. Thus, the oxidation of $\mathrm{Sn}$ from ö phase suggests an internal condition of lower oxygen potential, high enough to oxidize $\mathrm{Sn}$, but too low to oxidize $\mathrm{Cu}$ and to efficiently passivate the tin-rich $\delta$ phase. Low aerated environments can occur naturally, due to variations in soil conditions or, due to the formation of a rather thick corrosion layer changing the aeration conditions near the bulk.

In Famalicão and Coruche samples, both a phase and ö phase preferential corrosion layers can be observed simultaneously. In Famalicão's fragment (Fig. 13) at one side of the cross-section (upper part in Fig. 13a) the preferential corrosion of the $\alpha$ phase occurs and, on the other side, a layered structure, where both a and ö phases preferential corrosion is present, occurs. This layered structure is also observed in Coruche's sample. In both cases, this phenomenon appears in areas with a rather thick corrosion, indicating the development of a low aerated internal region.

Similarly, in Tarouca's sample both corrosion mechanisms were observed, however occurred in a reverse sequence (Fig. 14). The pseudomorphic corrosion presented by this sample suggests that it initially suffered $\delta$ phase preferential corrosion near the surface and only after suffered the corrosion of the $\alpha$ phase. Possibly, the latter corrosion only occurred after the excavation of the fragment, when it was exposed to a more aerated environment.

Note that the corrosion structure observed on Famalicão (area marked in Fig. 13a) and Coruche samples is not commonly observed or reported in bronze corrosion structures. To our knowledge, a clear evidence of corroded $\delta$ phase and uncorroded $\alpha$ phase of an internal sublayer (2b) were only reported in high-tin bronzes [24, 32, 44, 49], and rarely noticed on common bronzes [51, 52].
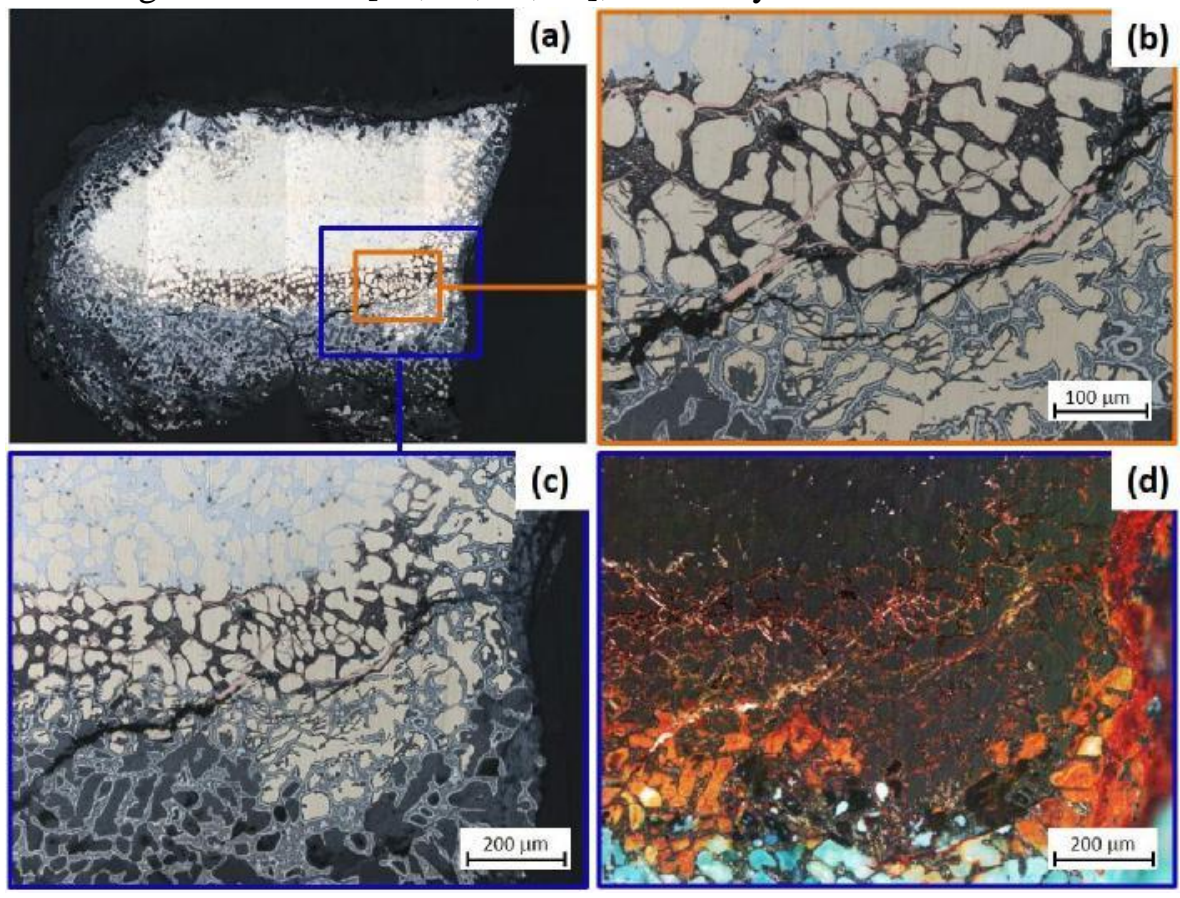

Fig. 13. (a) OM bright field image of the Famalicão cross-section. (b, c) Magnified bright field OM images of the corrosion on the bottom of the cross-section showing two different corrosion layers $(200 \times, 100 \times)$ and (d) corresponding polarized light image which shows transformation of yellow-red corrosion products in green corrosion products. 


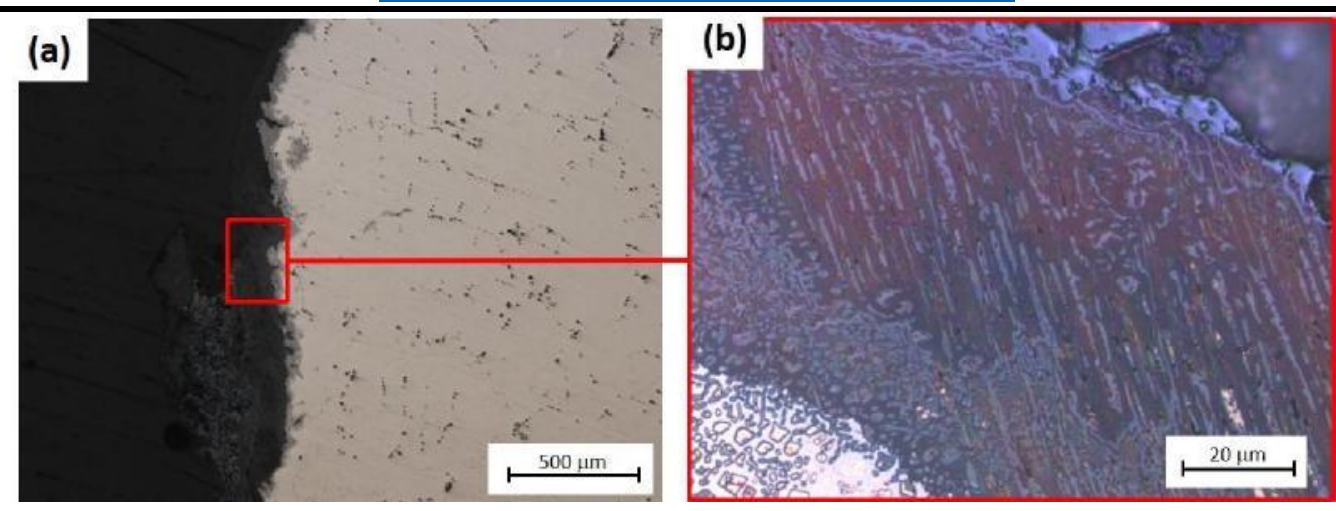

Fig. 14. (a) Detailed OM images of Tarouca's cross-section showing the external corrosion, bright field $(100 \times)$ and (b) pseudomorphic corrosion structure observed near the surface of the fragment, bright field, $(1000 \times)$.

\subsubsection{Identification of corrosion products on sublayer $2 b$}

The SEM-EDS microanalysis of the corroded $\delta$ phase in Famalicão's sublayer $2 b$, shows the presence of $\mathrm{Cu}(12.9 \pm 1.8$ at.\%), Sn (17.17 \pm 0.5 at.\%) and $\mathrm{O}(69.91 \pm 1.3$ at.\%). Assuming that copper is in metallic form, the $\mathrm{O} / \mathrm{Sn}$ atomic ratio is of $4.03 \pm 0.05$ at/at. If copper is assumed to be incorporated in the tin oxide ( $\mathrm{Cu}$ atoms incorporated by substitution in the tin oxide structure) the $\mathrm{O} / \mathrm{Sn}$ ratio drops to $2.37 \pm 0.15$ at/at, a ratio close to the $\mathrm{SnO}_{2}$. These analyses might confirm that $\mathrm{Cu}$ is at an oxidized state when present at ö corroded.

The same microanalysis carried out in Tarouca's sample oxidized ö phase (sublayer $2 b$ ) resulted in a measure of the atomic $\mathrm{O} / \mathrm{Sn}$ ratio of 4.1 at/at. The $\mathrm{Cu}$ content in the analyzed spot was 12.1 at.\%. Once again, assuming that the copper atoms are incorporated in the oxide structure, this ratio falls to 2.4. Like in Famalicão's bell, this suggests a $\left(\mathrm{Sn}_{1-\mathrm{x}} \mathrm{Cu}_{\mathrm{x}}\right) \mathrm{O}_{2}$ oxide. Considering the stoichiometric excess of oxygen in both cases, the formed compound is most probably partially hydrated.

To better characterise the $\mathrm{O} / \mathrm{Sn}$ atomic ratio of the tin oxide formed in these sublayers, Famalicão's sample was subjected to a desiccated operation $\left(60{ }^{\circ} \mathrm{C}\right.$ during 24 hours in a ventilated oven) to reduce the hydration effect due to the metallographic preparation of the sample, and new analysis in a SEM-FIB with high resolution were performed.

An EDS line scan was performed over the cross-section in sublayer 2b (Fig. 15), starting in the corroded $\delta$ phase and crossing the grain boundary to an $\alpha$ grain. A measure of the atomic $\mathrm{O} / \mathrm{Sn}$ ratio in the oxidized ö resulted in the value $2.8 \pm 0.5$ at/at. The copper content was $8.7 \pm 0.5$ at. $\%$, assuming that the copper atoms are incorporated in the oxide structure, this ratio drops to $2.05 \pm 0.40$ at/at confirming, again, the presence of some copper in the tin oxide structure. Ignoring the presence of other species detected in low amounts, like $\mathrm{Cl}$ and $\mathrm{S}$, this value suggests the oxidation of $\delta$-phase to tin (IV) oxide with copper atoms incorporated in its structure. The comparison of the $\mathrm{O} / \mathrm{Sn}$ ratio obtained before and after the exsiccation confirms that there are no significant differences between the two, thus indicating that if water is present, it is mostly incorporated in the mineral structure (combined water) and its presence is not a consequence of the metallographic preparation. 


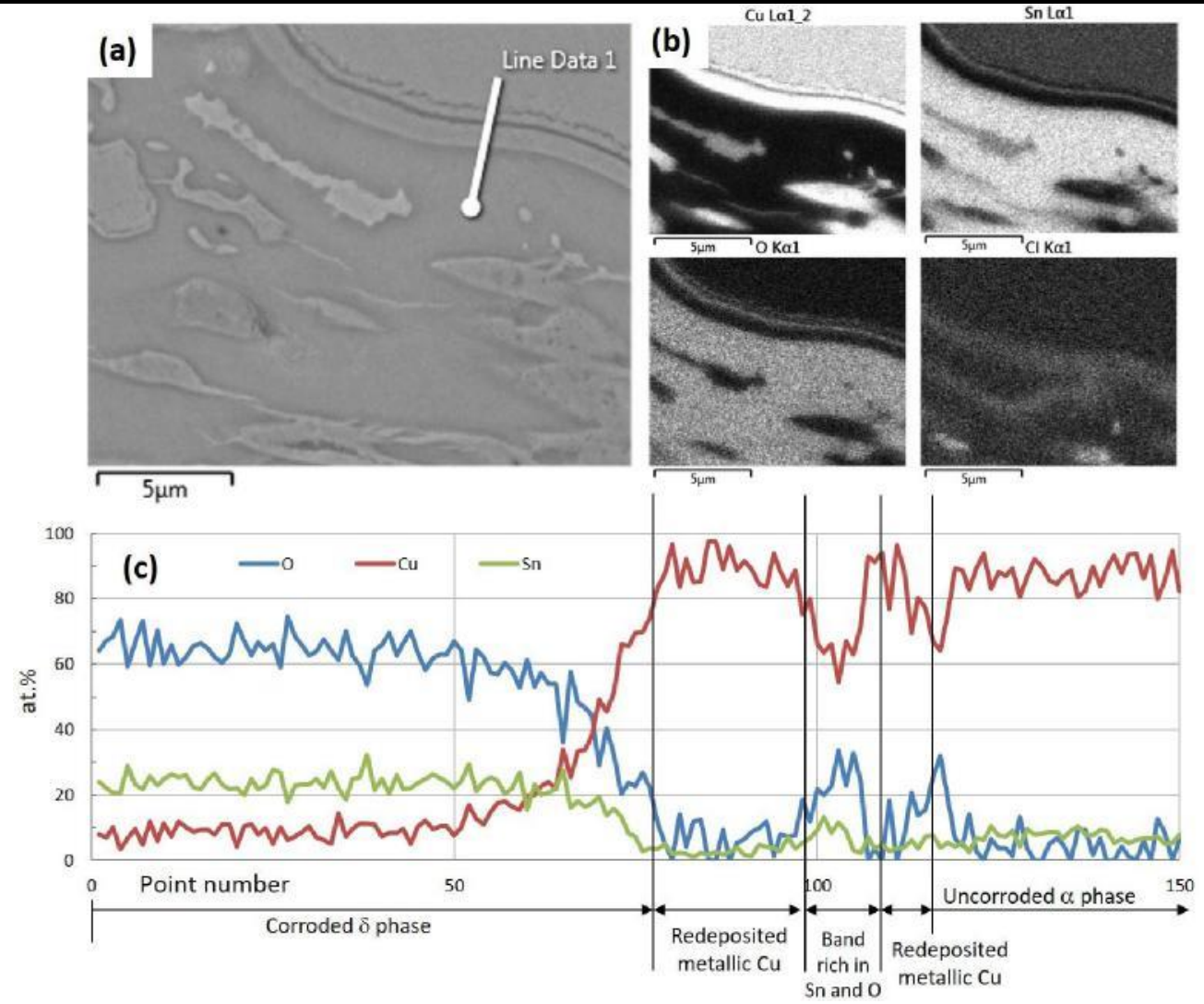

Fig. 15. (a) BSE-SEM image of Famalicão bell cross-section (after the desiccated process) and (b) corresponding EDS elemental mappings. (c) Line scan contents profiles for $\mathrm{Cu}, \mathrm{Sn}$ and $\mathrm{O}$ atomic contents (normalized to 100\%). The line scan crosses the grain boundary of the oxidize $\delta$ phase and an $\alpha$ grain in the inner corrosion layer.

The X-ray profile information, together with the X-ray elemental maps evidenced an interesting phenomenon in the grain boundaries between $\alpha$ and corroded eutectoid $\delta$ phase. A small band rich in $\mathrm{Sn}$ and $\mathrm{O}$ between two bands of redeposited copper were observed. The thickest band of $\mathrm{Cu}$ may be related to the $\mathrm{Cu}$ redeposited after the oxidation of the $\delta$ phase and is present nearer the limit of the preexisting $\delta$ phase grain. The other bands, closer to the $\alpha$ grain could be explained by tin oxidation in the $\alpha$ grain border followed by its segregation to the grain boundary and precipitation in oxide form, leaving a $\mathrm{Cu}$ rich band behind that was further partially oxidized.

Raman analysis were carried out with the objective of characterising the Sn oxidized species formed in the preferential corrosion of the $\delta$ phase in sublayer $2 \mathrm{~b}$. The aim was to understand the reason for which tin compounds in sublayer $2 \mathrm{~b}$ don't form a passive layer similarly to what happens at higher oxygen potentials, like in sublayer $2 \mathrm{a}$, and investigate if cassiterite is the main specie in this situation or if another tin corrosion product is formed. In order to do so, Famalicão's sample was chosen to be analysed due to the presence of a higher extent of this corrosion pattern.

Figure 16 shows the Raman scattering spectrum and a Raman image at maximum vibration intensity of $621 \mathrm{~cm}^{-1}$. The selected area was a region with a continuous and thick layer of $\delta$ phase among primary $\alpha$ phase grains. The Raman spectrum obtained shows one strong and broad peak at $621 \mathrm{~cm}^{-1}$ at the maximum intensity of vibration and a secondary peak at $276 \mathrm{~cm}^{-}{ }^{1}$. A search of all Raman spectra for minerals with chemistry including $\mathrm{Sn}, \mathrm{Cu}, \mathrm{O}, \mathrm{Cl}$ and $\mathrm{H}$ in IMA Database of Mineral Properties/ RRUFF Project [53] did not allow the identification of any spectra that exactly fitted the acquired scattering spectrum. However, there is a close coincidence of the Raman shift for these two peaks with the data from mineral cassiterite (RUFF, ID data R040017). The deviations observed in the obtained spectra may be caused by the incorporation of some 
copper ions in the cassiterite-like structure. Past investigation on ancient Chinese mirrors [38], also detected a mixed oxide of $\mathrm{Cu}$ and $\mathrm{Sn}$ on their surface, $\left(\mathrm{Sn}_{1-\mathrm{x}} \mathrm{Cu}_{\mathrm{x}}\right) \mathrm{O}_{2}$, where $\mathrm{x} \approx 0.16$. In another study, Wang [54] identified on the surface of black Chinese mirrors, nanoparticles with about $5 \mathrm{~nm}$ of $\mathrm{Sn}_{1_{-}}(\mathrm{Cu}, \mathrm{Fe}, \mathrm{Pb}, \mathrm{Si})_{\mathrm{x}} \mathrm{O}_{2}$. Both oxides identified in these studies suggest a cassiteritelike structure. Present SEM-EDS results of desiccated Famalicão fragment also suggest an oxide $\left(\mathrm{Sn}_{1-\mathrm{x}} \mathrm{Cu}_{\mathrm{x}}\right) \mathrm{O}_{2}$ where $\mathrm{x}=0.26 \pm 0.06$. The detection of some amounts of $\mathrm{Cl}(1.64 \pm 1.04$ at.\%) and $\mathrm{S}(1.07 \pm 0.96$ at.\%) in the analyzed line range could also indicate a more complex composition. The Raman image mapping at a fixed frequency for the principal mode of vibration found (621 $\mathrm{cm}^{-1}$ ) seems to evidence the polycrystalline dimension of the tin oxide particles, due to the observed variations in the signal intensity in the mapping image (Fig. 16).

Deviations observed in the obtained Raman spectrum may also result of the hydration of the oxide formed, being this spectrum very similar to one obtained for a brown tin product observed in a remain of a corroded tin solder of a fragment from a Kyathos vase (K4 sample), which was identified by the authors as $\mathrm{SnO}_{2} . \mathrm{H}_{2} \mathrm{O}$ [42].

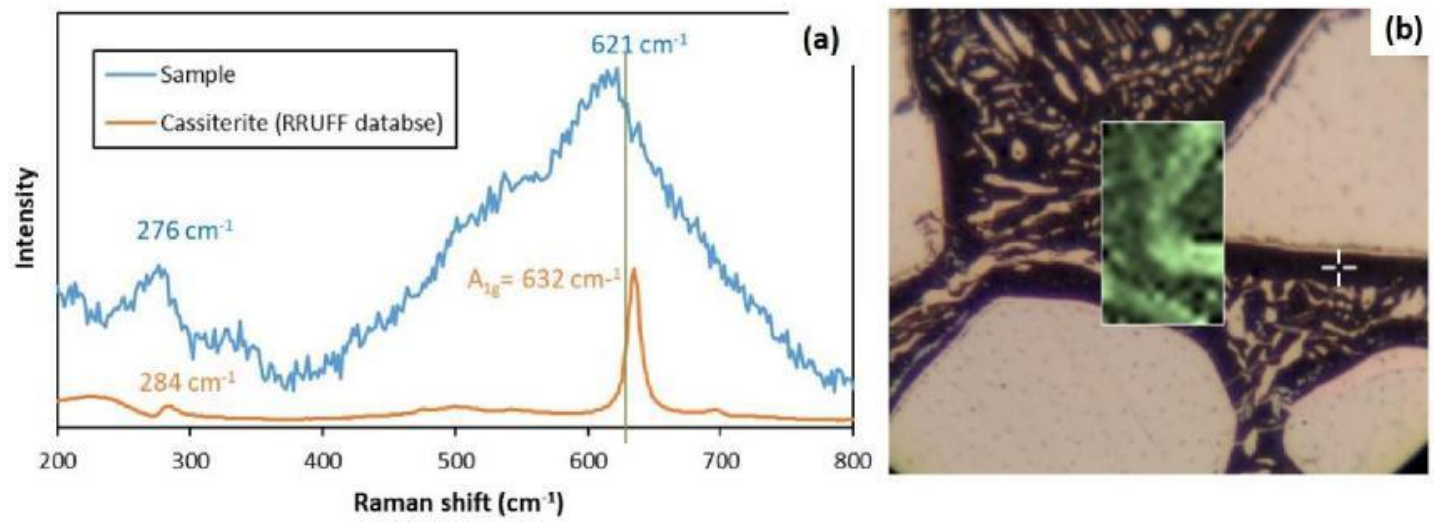

Fig. 16. Raman analyses of Famalicão cross-section performed in oxidised ö phase region. (a) Raman spectrum with nonpolarized light excitation and (b) image mapping (inserted box in the OM image) at a fixed frequency of $621 \mathrm{~cm}^{-1}$.

Mainly, the presence of copper within the cassiterite structure can explain the lower passivation efficiency of the $\delta$ phase observed at lower oxygen potentials, since the remain of copper results necessarily in a more imperfect crystalline structure, facilitating the diffusion of oxygen. The permanence of these copper atoms in the cassiterite structure should be caused by a lower leaching rate of copper atoms in low oxygen potential regions, associated with its lower tendency to oxidation.

\subsection{Final discussion}

The present study defines two corrosion conditions related to different oxygen potentials in archaeological high tin bronzes. Condition A, under high oxygen potential levels, leads to the preferential corrosion of the $\alpha$ phase and the passivation of the $\delta$ phase, richer in tin. Condition $\mathrm{B}$, under low levels of oxygen, results in the preferential corrosion of the $\delta$ phase and redeposition of metallic copper, being the $\alpha$ phase left uncorroded. Bearing in mind that the soil properties and chemical composition can change with time $[23,55]$ and consequently cause variation of oxygen potential, structures originally of Condition A can evolve to structures typical of Condition B and vice-versa. In Fig. 17 a scheme with possible evolutions is shown with the resulting microstructures. The scheme summarizes the different patterns observed in the samples and is thus of major relevance for future microstructural interpretations. 


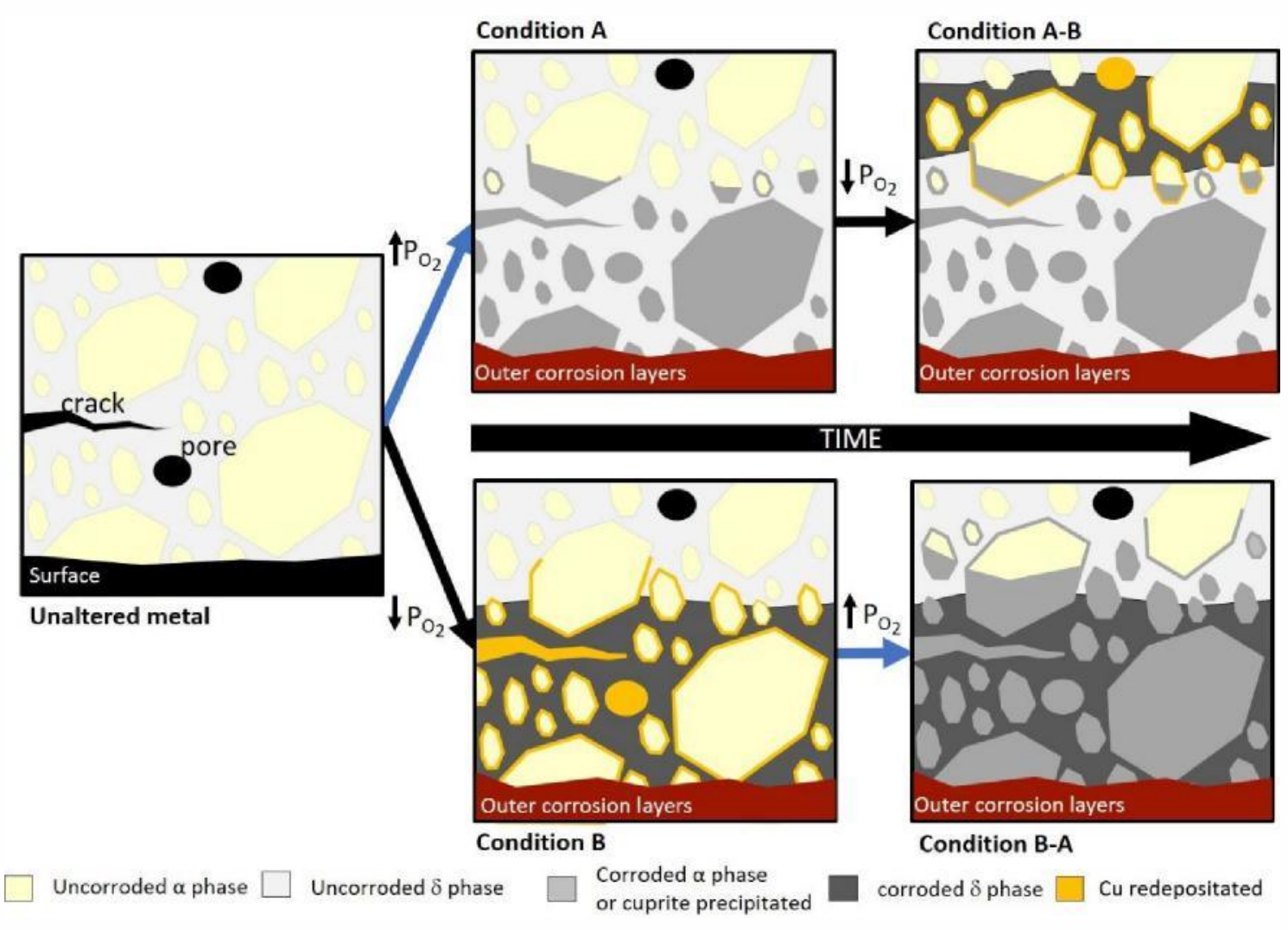

Fig. 17. Schematic representations of the microstructure of a bronze before corrosion, consisting of $\alpha-\mathrm{Cu}$ and ö phases and presenting some voids and cracks, and its internal corrosion after been exposed to different conditions: condition A (higher oxygen potential), condition B (lower oxygen potentials) after transition from A to B and after transition from $\mathrm{B}$ to A conditions.

More than one corrosion condition can be detected in one sample, as it was for Famalicão, Tarouca and Coruche samples. These are a result of environmental changes during burial time or a result of the presence of thick corrosion layers at the surface, causing low oxygen potentials in internal areas towards the corrosion progression. Near the external surfaces of the samples, where the oxygen potential is normally higher, the corrosion is developed preferentially at the $\alpha$ phase and the tin-rich $\delta$ phase is passivated. In the internal areas and/or when the object is in low aerated environments, the preferencial corrosion of the $\delta$ phase is the most common phenomenon, occurring simultaneously with the redeposition of metallic copper.

Condition A corrosion is expected to be the most common among archaeological bronzes. Condition B can be associated with the presence of a "network" of $\delta$ phase (surrounding the $\alpha$ phase grains) that occurs in higher-tin bronzes. The occurrence of both conditions in one object although observed should be less frequent, as it implies a drastic change in the environment. Condition B-A should be rarer because it imposes an evolution from condition B (less aerated and less common) to condition A (more aerated), which is associated with increased oxygen potential in the corrosion front during burial.

\section{Conclusions}

The present study aimed to clarify the different corrosion patterns observed on archaeological hightin bronze artefacts and infer about their formation conditions. The long-term corrosion of high-tin bronzes was studied, leading to the characterisation of a set of four different corrosion structures. Two distinct corrosion phenomena were observed and described: (A) the preferential corrosion of $\alpha$ phase that arises in more aerated environments and (B) the preferential corrosion 
of $\delta$ phase with metallic copper redeposition in low oxygenated environments. Both phenomena could be present on the same object, due to the occurrence of environmental modifications during burial time or due to long-term corrosion under low aggressive environments with the formation of thick corrosion layers. It was also possible to conclude that decuprification is the primary corrosion phenomenon occurring in these materials, in both $\alpha$ and $\delta$ phases.

A proposal for the evolution of the corrosion structures observed in high tin bronzes (A to B or $\mathrm{B}$ to A) was schematized as a function of the variation of environmental aeration conditions. This aims to help the future correct identification of the corrosion patterns of two phased bronze artefacts. The proposed terminology aims to the facilitation of the communication among the various professionals dealing with cultural bronze objects.

\section{Funding Details}

Part of this work has been carried out in the framework of the projects: "Singing Bronze", funded by Santander-Totta through the prize Santander/NOVA 2016; "IberianTin" (PTDC/HAR-ARQ/32290/2017), funded by FEDER funds through the regional program of Lisbon and through national funds through the Portuguese Science Foundation (FCT) and UID/CTM/50025/2019 granted to CENIMAT/i3N, financed through FEDER funds by COMPETE 2020 and national funds through FCT.

Elin Figueiredo https://orcid.org/0000-0002-4821-3895

Hugo Âguas https://orcid.org/0000-0001-7350-649X

Rui J. C. Silva https://orcid.org/0000-0002-0914-8517

\section{References}

[1] G. M. Ingo, P. Plescia, E. Angelini, C. Riccucci, e T. De Caro, «Bronze roman mirrors: the secret of brightness», Applied Physics A, vol. 83, pp. 611-615, 2006.

[2] P. Price, «Bell (i)», The New Grove Dictionary of Music and Musicians, vol. 1. Oxford University Press, 2001.

[3] L. Sebastian, História da Fundição Sineira em Portugal. Coruche: Museu Municipal de Coruche, 2008.

[4] J. Audy e K. Audy, «Analysis of Bell materials: Tin Bronzes», China Foundry, vol. 58, n. 1, pp. 199-204, 2009.

[5] Theophilus, On Divers Arts - The Foremost Medieval Treatise on Painting, Glassmaking and Metalwork. New York: Dover, 1979.

[6] V. Biringuccio, The Pirotechnia of Vannoccio Biringuccio. New York: The American Institute of Mining and Metallurgical Engineers, 1943.

[7] G. Hiscox, Ed., Henley's Twentieth Century Book of Recipes, Formulas and Processes. New York, 1914.

[8] M. Nadolski, «The Evaluation of Mechanical Properties of High-tin Bronzes», Archives of Foundry Engineering, vol. 17, n. 1, pp. 127-130, 2017.

[9] A. Vazdirvanidis e G. Pantazopoulos, «Metallographic Study of Great Anthony Historical Bronze Bells of Apostle Andrew Skete in Mount Athos, Greece», Metallogr. Microstruct. Anal., vol. 6, pp. 340-351, 2017.

[10] J. H. Arnold e C. Goodson, «Resounding community: the History and Meaning of Medieval Church Bells», Viator, vol. 43, n. 1, pp. 99-130, 2012.

[11] M. Carvalho, «Os carrilhões de Mafra: estudo e caracterização acústica dos sinos», Master Thesis, Faculdade de Ciências Sociais e Humanas- Universidade Nova de Lisboa, Lisboa, 2012.

[12] P. F. da Costa, «Sons do Tempo: usos sociais e simbólicos do sino na cultura popular», em Subsídios para a História da Fundição Sineira em Portugal - Do sino medieval da Igreja de São Pedro de Coruche à atualidade, Coruche: Museu Municipal de Coruche, 2008.

[13] L. Rombouts, Singing Bronze - A History of Carillon Music. Leuven: Lipisius Leuven, 2014.

[14] R. T. Paula, «O "som brônzeo" da morte: Poder e liturgia fúnebre a partir da torre sineira da Santa Igreja Patriarcal de Lisboa (1730-69)», Revista Portuguesa de Musicologia, vol. 5, n. 1, pp. 93-116, 2018. 
Saraiva, A.S., Figueiredo, E., Águas, H., Silva, R.J.C. (2020) Characterisation of Archaeological High-tin Bronze Corrosion Structures, Studies in Conservation, https://doi.org/10.1080/00393630.2020.1857523.

[15] D. A. Scott, Metallography and Microstructure in Ancient and Historic Metals: Getty Conservation Institute, 1992.

[16] R. Marreiros, «Avaliação das constantes elásticas de bronzes vazados com alto teor em estanho», Master Thesis, Faculdade de Ciências e Tecnologia - Universidade Nova de Lisboa, Monte da Caparica, 2014.

[17] N. Saunders e A. P. Miodownik, «The Cu-Sn (Copper-Tin) System», Bulletin of Alloy Phase Diagrams, vol. 11, n. 3, pp. 278-287, 1990.

[18] C. T. des I. de la F. Paris, Atlas Metallographique Des Alliages Cuivreux. Ed. Techn. des Ind. de la Fond., 1967.

[19] G. M. Ingo et al., «Large scale investigation of chemical composition, structure and corrosion mechanism of bronze archaeological artefacts from Mediterranean basin», Applied Physics A, vol. 83, pp. 513-520, 2006.

[20] V. K. Gouda, G. I. Youssef, e N. A. Abdel Ghany, «Characterization of Egypcian bronze archaeological artifacts», Surface and Interface Analysis, vol. 44, pp. 1338-1345, 2012.

[21] G. M. Ingo, I. Calliari, M. Dabala, G. Bultrini, T. De Caro, e G. Chiozzini, «Microchemical study of the corrosion products on ancient bronzes by means of glow discharge optical emission spectrometry», Surface and Interface Analysis, vol. 30, pp. 264-268, 2000.

[22] V. Debut, M. Carvalho, E. Figueirdo, J. Antunes, e R. Silva, «The sound of bronze: Virtual resurrection of a broken medieval bell», Journal of Cultural Heritage, vol. 19, pp. 544-554, 2016.

[23] L. Robbiola, J.-M. Belengino, e C. Fiaud, «Morphology and Mechanisms of Formation of Natural Patinas on Archaeological Cu-Sn Alloys», Corrosion Science, vol. 40, n. 12, pp. 2083-2111, 1998.

[24] W. T. Chase, «Chinese Bronzes: Casting, Finishing, Patination and Corrosion», em Ancient \& Historic Metals: Conservation and Scientific Research, Getty Publications, 1994.

[25] M. F. Alberghina, R. Barraco, M. Brai, T. Schillaci, e L. Tranchina, «Integrated analytical methodologies for the study of corrosion processes in archaeological bronzes», Spectrochimica Acta Part B, vol. 66, pp. 129-137, 2011.

[26] K. Trentelman, L. Stodulski, R. Lints, e C. Kim, «A Comparative Study of the Composition and Corrosion of Branches from Eastern Han Dynasty Money Trees», Studies in Conservation, vol. 44, n. 3, pp. 170-183, 1999.

[27] F. Ospitali, C. Chiavari, C. Martini, E. Bernardi, F. Passarini, e L. Robbiola, «The characterization of Sn-based corrosion products in ancient bronzes: a Raman approach», Journal of Raman Spectroscopy, vol. 43, pp. 1596-1603, 2012.

[28] J. Muller, G. Lorang, E. Leroy, B. Laik, e I. Guillot, «Electrochemically synthesised bronze patina: characterisation and application to the cultural heritage», Corrosion Engineering, Science and Technology, vol. 45, n. 5, pp. 322-326, 2010.

[29] G. M. Ingo, E. Angelini, T. De Caro, G. Bultrini, e A. Mezzi, «Combined use of XPS and SEM+EDS for the study of surface microchemical structure of archaeological bronze Roman mirrors», Surface and Interface Analysis, vol. 36, pp. 871-875, 2004.

[30] I. De Ryck, E. Van Biezen, K. Leyssens, A. Adriaens, P. Storme, e F. Adams, «Study of tin corrosion: the influence of alloying elements», Journal of Cultural Heritage, vol. 5, pp. 189-195, 2004.

[31] S. Jouen, B. Hannoyer, e O. Piana, «Non-destructive surface analysis applied to atmospheric corrosion of tin», Surface and Interface Analysis, vol. 34, pp. 192-96, 2002.

[32] W. T. Chase, M. Notis, e A. P. Pelton, «New Eh-pH (Pourbaix) diagrams of the copper tin system», em Metal 07, Amesterdam, 2007, vol. 3 "Use of electrochemical techniques in metal conservation", pp. 15-21.

[33] L. Robbiola, C. Fiaud, e A. Harch, «Characterization of passive layers of bronze patinas (Cu-Sn alloys) in relation with the tin content of the alloy», Paris, 1994, vol. 577, pp. 150-154.

[34] J. Muller, B. Laïk, e I. Guillot, «a-CuSn bronzes in sulphate medium: Influence of the tin content on corrosion processes», Corrosion Science, vol. 77, pp. 46-51, 2013.

[35] M. C. Bernard e S. Joiret, «Understanding corrosion of ancient metals for the conservation of cultural heritage», Electrochimica Acta, vol. 54, pp. 5199-5205, 2009.

[36] K. Kareem, S. Sultan, e L. He, «Fabrication, microstructure and corrosive behaviour of different metallographic tin-leaded bronze alloys part II: Chemical corrosive behaviour and patina of tinleaded bronze alloys», Material Chemistry and Physics, vol. 169, pp. 158-172, 2016.

[37] M. J. Hutchinson e J. R. Scully, «Patina enrichment with $\mathrm{SnO} 2$ and its effect on soluble Cu cation release and passivity of high-purity $\mathrm{Cu}$-Sn bronze in artificial perspiration», Electrochimica Acta, vol. 283, pp. 806-817, 2018. 
Saraiva, A.S., Figueiredo, E., Águas, H., Silva, R.J.C. (2020) Characterisation of Archaeological High-tin Bronze Corrosion Structures, Studies in Conservation, https://doi.org/10.1080/00393630.2020.1857523.

[38] N. D. Meeks, «Tin-rich surfaces on Bronze - Some experimental and Archaeological considerations», Archeometry, vol. 28, n. 2, pp. 133-162, 1986.

[39] J. Allen, Battles of the British Navy, vol. 1. H. G. Bohn, 1853.

[40] F. J. S. Alves, «O itinerário arqueológico subaquático do Océan», O Arqueólogo Português, vol. 8, n. 10, pp. 455-467, 19921990.

[41] E. Figueirdo, R. J. C. Silva, M. F. Araújo, e F. M. Braz Fernandes, «Multifocus optical microscopy applied to the study of archaeological metals», Microscopy and Microanalysis, vol. 19, pp. 12481254, 2013, doi: 10.1017/S1431927613001608.

[42] P. Piccardo e L. Robbiola, «Tin and copper oxides in corroded archaeological bronzes», em Corrosion of Metallic Heritage Artifacts - Investigation, Conservation and Prediction of Long Term Behaviour, 2007, pp. 239-262.

[43] D. A. Scott, «Fractal Forms and the Deterioration of Artefacts», Studies in Conservation, vol. 50, n. 3, pp. 179-189, 2005.

[44] R. J. C. Silva, E. Figueirdo, M. F. Araújo, F. Pereira, e F. M. Braz Fernandes, «Microstructure Interpretation of Copper and Bronze Archaeological Artefacts from Portugal», Materials Science Forum, vol. 587-588, pp. 365-369, 2008.

[45] K. Osseo-Asare e K. K. Mishra, «Solution Chemical Constraints in the Chemical-Mechanical Polishing of Copper: Aqueous Stability Diagrams for the $\mathrm{Cu}-\mathrm{H} 20$ and $\mathrm{Cu}-\mathrm{NH} 3-\mathrm{H} 20$ Systems», Journal of Electronic Materials, vol. 25, n. 10, pp. 1599-1607, 1996.

[46] D. A. Scott, «Periodic Corrosion Phenomena in Bronze Antiquities», Studies in Conservation, vol. 30, pp. 49-57, 1985.

[47] M. G. Fontana, Corrosion Engineering, 3rd edition. McGraw-Hill Internation Edition, 1986.

[48] C. Bosi, G. L. Garagnani, V. Imbeni, C. Martini, R. Mazzeo, e G. Poli, «Unalloyed copper inclusions in ancient bronze artefacts», Journal of Materials Science, vol. 37, pp. 4285-4298, 2002.

[49] Q. Wang e J. F. Merkel, «Studies on the Redeposition of Copper in Jin Bronzes from Tianma-Qucun, Shanxi, China», Studies in Conservation, vol. 46, n. 4, pp. 242-250, 2001.

[50] G. M. Ingo et al., «Surface studies of patinas and metallurgical features of uncommon high-tin bronze artefacts from the Italic necropolises of ancient Abruzzo (Central Italy)», Applied Surface Science, vol. 470, pp. 74-83, 2019.

[51] R. J. Taylor e I. D. MacLeod, «Corrosion of Bronzes on Shipwrecks», Corrosion, vol. 41, n. 22, pp. 100-104, 1985.

[52] E. Figueirdo, «A study on metallurgy and corrosion of ancient copper-based artefacts from the Portuguese territory», PhD thesis, Universidade Nova de Lisboa, Lisbon, 2010.

[53] «RUFF database», RRuff. http://rruff.info/ (acedido Fev. 08, 2019).

[54] C. Wang et al., «Structural and elemental analysis on the nanocrystalline $\mathrm{SnO} 2$ in the surface of ancient Chinese black mirrors», Nanostrucutred Materials, vol. 5, n. 4, pp. 489-496, 1995.

[55] O. Oudbashi, «A methodological approach to estimate soil corrosivity for archaeological copper alloy artefacts», Heritage Science, vol. 6, n. 2, 2018. 